\title{
Pembangunan dan Pelatihan Sistem Pendidikan Guna Meningkatkan Profesionalisme Relawan pada PMI Kota Tangerang
}

\author{
Euis Sitinur Aisyah ${ }^{1}$, Ratna Nur Aulia ${ }^{1}$, Ridhoi Ahmad Ridwan ${ }^{2}$ \\ ${ }^{1}$ Sistem Informasi, Fakultas Sains dan Teknologi, Universitas Raharja, \\ Jalan Jend. Sudirman No. 40, Kota Tangerang, 15117 \\ ${ }^{2}$ Teknik Informatika, Fakultas Sains dan Teknologi, Universitas Raharja, \\ Jalan Jend. Sudirman No. 40, Kota Tangerang, 15117 \\ Penulis untuk Korespondensi/E-mail: ratna.aulia@raharja.info
}

Abstrak - Sistem pendidikan dan pelatihan pada PMI Kota Tangerang yang berjalan saat ini masih semi komputerisasi. Pengetesan dan penilaian materi masih manual sehingga sering terjadi kesalahan input nilai peserta, memerlukan proses dan waktu yang cukup lama untuk mengetahui kelulusan peserta diklat yang mengakibatkan terlambatnya laporan panitia kepada Kadiv SDM. Metode penelitian yang digunakan terdiri dari wawancara, observasi, dan studi pustaka. Metode analisis menggunakan metode analisis PIECES. Pemodelan sistem dengan menggunakan Unified Modelling Language (UML) untuk menggambarkan secara visualisasi, yang selanjutnya diimplementasikan dengan bahasa pemrograman PHP dengan basis data MySQL-Server sebagai database. Hasil yang didapat dari penelitian ini adalah sebuah sistem aplikasi diklat relawan PMI berbasis web yang terdatabase untuk membantu dalam hal pengelolaan data mulai dari pendaftaran, pemberian materi, keadiran, pengetesan, dan penilaian.

Abstract - The education and training system at the PMI Kota Tangerang that is currently running is still semi-computerized. The testing and evaluation of material are still manual so that there are often input errors in the participants' scores, it requires a long process and time to find out the graduation of the training participants which results in the delay of the committee's report to the Head of HR Division. The research method used consisted of interviews, observation, and literature study. The analytical method uses the PIECES analysis method. Modeling the system using Unified Modeling Language (UML) to visualize, which is then implemented with the PHP programming language with the MySQL-Server database as a database. The results obtained from this study are a web-based PMI volunteer education and training system database that is assisted regarding data management ranging from registration, material delivery, presence, testing, and assessment.

Keywords - Education and Training, Systems, Volunteers

\section{PENDAHULUAN}

P endidikan dan pelatihan adalah proses penyelenggaraan belajar mengajar dalam rangka meningkatkan kemampuan sumber daya manusia dan merupakan salah satu aspek penting yang harus diperhatikan dalam suatu instansi. Pendidikan dan pelatihan merupakan suatu hal yang tidak bisa dipisahkan dalam dunia ketenagakerjaan. Pada dasarnya pendidikan dan pelatihan memberikan bantuan kepada karyawan agar dapat meningkatkan kemampuan kerja dan menumbuhkan pengertian tentang status dirinya dan tujuan perusahaan (Ranupandojo dan Husnan) [1]. Pelatihan merupakan bagian dari investasi SDM (human investment) untuk meningkatkan kemampuan dan keterampilan kerja sehingga meningkatkan kinerja pegawai [2]. Untuk menunjang efektivitas dan efisiensi pekerjaan, setiap karyawan yang diberikan pelatihan di internal maupun eksternal dari instansi perlu pendataan dan hasil pelatihan tersebut harus diimplementasikan dalam setiap pekerjaannya.

Palang Merah Indonesia (PMI) adalah sebuah organisasi perhimpunan nasional di Indonesia yang bergerak dalam bidang sosial kemanusiaan. Peran PMI adalah membantu pemerintah di bidang sosial 
kemanusiaan, terutama tugas kepalangmerahan sebagaimana dipersyaratkan dalam ketentuan konvensi-konvensi jenewa 1949 yang telah diratifikasi oleh pemerintah Republik Indonesia pada tahun 1958 melalui UU No 59. PMI telah berada di 34 PMI Daerah (tingkat provinsi) dan sekitar 408 PMI Cabang (tingkat kota/kabupaten) di seluruh Indonesia.

Palang Merah Indonesia (PMI) cabang Kota Tangerang setiap tahunnya mengadakan diklat pada calon relawan dengan pendaftar mencapai 150 orang. Dalam proses diklat para calon relawan diberikan ilmu pengetahuan tentang kegiatan kegiatan PMI dimentori oleh fasilitator bersertifikasi. Nantinya para relawan akan diterjunkan di kegiatan-kegiatan kemanusiaan khususnya pelayanan sosial kemasyarakatan, penanggulangan bencana dan pengembangan kapasitas anggota.

Sistem pendidikan dan pelatihan yang berjalan pada PMI Kota Tangerang saat ini masih secara semi komputerisasi, yaitu sebatas menginput formulir calon relawan, pengelolaan data, penyimpanan, dan pembuatan laporan. Dalam sistem diklat yang berjalan saat ini sering mengalami kesulitan dalam proses administrasi registrasi diklat, banyaknya kertas yang digunakan untuk mencetak materi yang diberikan oleh fasilitator, presensi dan absensi yang terlewat, pengetesan dan penilaian materi masih manual yang akhirnya sering kali kesalahan dalam menginput nilai peserta, memerlukan proses dan waktu yang cukup lama untuk mengetahui kelulusan peserta diklat sehingga laporan yang diberikan panitia kepada Kadiv SDM mengalami keterlambatan dan memperlambat pelaksanaan pelantikan calon relawan.

Tujuan dari penelitian ini adalah

1. Mengetahui sistem Pendidikan dan pelatihan relawan pada PMI Kota Tangerang yang sedang berjalan saat ini, apakah sudah efektif dan efisien.

2. Mengetahui kendala yang sering terjadi di dalam sistem berjalan saat ini.

3. Menghasilkan rancangan sistem informasi Pendidikan dan Pelatihan relawan di PMI Kota Tangerang.

\section{METODE}

\section{Tempat dan Waktu Penelitian}

Penelitian dilaksanakan di PMI cabang Kota Tangerang yang terletak di Jl. Mayjen Sutoyo no. 15
Kota Tangerang. Penelitian ini dilakukan selama 5 (lima) bulan, dimulai dari Februari 2020 sampai dengan Juli 2020.

\section{Metode Pengumpulan Data Observasi}

Observasi dilakukan dengan cara pengamatan langsung atau peninjauan secara cermat pada objek yang diteliti. Dalam hal ini peneliti mendatangi langsung kegiatan Diklat di PMI Kota Tangerang untuk mengamati proses kegiatan dan bertemu kepala divisi bagian SDM untuk meminta data yang diperlukan seperti data peserta yang mengikuti diklat serta data pengukuran skala penilaian pada diklat di PMI Kota Tangerang.

\section{Wawancara}

Peneliti melakukan penelitian dengan cara wawancara atau tanya jawab secara lisan dan tertulis kepada Kepala Divisi SDM di PMI Kota Tangerang untuk mendapatkan data informasi terkait objek yang diteliti.

\section{Studi Pustaka}

Penelitian yang dilakukan untuk menghimpun informasi yang relevan dengan topik atau objek yang akan atau sedang diselidiki. Informasi tersebut diperoleh dari buku - buku ilmiah, laporan penelitian, karangan - karangan ilmiah, tesis dan disertasi, peraturan - peraturan, ketetapan ketetapan, buku tahunan, ensiklopedia, dan sumber - sumber tertulis baik tercetak maupun elektronika yang berkaitan dengan objek yang diteliti.

\section{Metode Perancangan}

Metode perancangan dalam penelitian ini menggunakan metode pengembangan sistem menggunakan model SDLC (Software Development Life Cycle). SDLC itu sendiri merupakan sebuah pola yang berfungsi untuk melakukan proses pembuatan maupun perubahan sistem dari sebuah aplikasi [3]. SDLC memiliki 5 tahapan pengerjaan, yaitu perencanaan (planning), analisis (analysis), Desain (design), implementasi (implementation), pemeliharaan (maintenance).

Tahap perencanaan adalah tahap awal pengembangan sistem yang mendefinisikan perkiraan kebutuhan-kebutuhan sumber daya, seperti: perangkat fisik, metode dan anggaran yang sifatnya masih umum. Di dalam tahapan ini juga terdapat beberapa aktivitas pada pengembangan sistem yaitu: Mendefinisikan tujuan dan ruang lingkup pengembangan, mengidentifikasi kendalakendala sistem, menentukan serta evaluasi strategi yang akan digunakan dalam pengembangan. 
Metode analisis kebutuhan yang di gunakan adalah PIECES (Performance, Information, Economic, Control, Efficiency, Service). "Analisis PIECES merupakan analisa yang digunakan untuk menganalisa tentang kinerja, informasi, ekonomi, pengendalian, efisiensi, dan pelayanan dari sistem lama dan sistem baru yang dibuat". [4]

Tahap desain menentukan proses dan data yang diperlukan oleh sistem baru dengan tujuan untuk memenuhi kebutuhan user dengan alat bantu UML (Unified Modeling Language). Unified Modeling Language (UML) merupakan bahasa visualisasi untuk permodelan dan komunikasi mengenai sebuah sistem dengan menggunakan diagram dan teks - teks pendukung [5]. Sebuah proses desain ini akan menerjemahkan syarat kebutuhan ke sebuah perancangan perangkat lunak yang dapat diperkirakan sebelum dibuat coding. Proses ini berfokus pada sebuah struktur data dengan menggunakan MySQL. MySQL adalah salah satu jenis database server yang sangat terkenal dan banyak digunakan untuk membangun aplikasi web yang database sebagai sumber dan pengolahan datanya [6].

Tahap implementasi merupakan tahap dimana rancangan sistem yang sudah jadi lalu dibentuk menjadi suatu kode (program) yang siap untuk dioperasikan. Langkah - langkahnya yaitu menyiapkan fasilitas fisik dan melakukan simulasi.

\section{HASIL DAN PEMBAHASAN}

\section{Perencanaan}

Perencanaan kebutuhan merupakan dari aplikasi yang akan dibuat dan merupakan tahap awal untuk menentukan informasi apa saja yang akan di sampaikan kepada pengguna aplikasi ini. Dalam melakukan penelitian ini dibutuhkan perangkat lunak dan perangkat keras untuk dapat menjalankan sistem pengolahan data [7]. Adapun perangkat keras dan perangkat lunak yang digunakan untuk sistem ini antara lain:
Perangkat keras (hardware), terdiri dari:

1. Processor minimal intel core i3 $1.80 \mathrm{GHz}$

2. RAM minimal $2 \mathrm{~GB}$

3. HDD minimal $500 \mathrm{~GB}$

4. Mouse dan Printer

Perangkat lunak (software), terdiri dari:

1. Sistem operasi minimal Windows 7

2. Microsoft Office 2016

3. Pdf viewer

4. XAMPP

5. Database server: MySQL

6. Sublime Text

7. Chrome

\section{Analisis}

Untuk mengidentifikasi masalah, harus dilakukan analisis terhadap kinerja, informasi, ekonomi, keamanan sistem, efisiensi dan pelayananpelayanan. Panduan ini dikenal dengan Analisis PIECES (Performance, Information, Economy, Control, Efficiency, Service) [8]. Dari analisis ini biasanya yang muncul bukan masalah utama, tetapi hanya gejala dari masalah utama saja.

Tabel 1. Analisis PIECES

No Jenis Analisis $\begin{gathered}\text { Kelemahan Sistem Yang } \\ \text { Berjalan }\end{gathered}$

1. Performance 1. Sistem yang saat ini (kinerja) digunakan seringkali menghambat waktu untuk pencarian data karena data yang tersebar tidak pada satu sistem.

2. Proses - proses dalam pelaksanaan diklat saat ini masih membutuhkan waktu yang lama terutama dalam proses input data peserta.

3. Sistem saat ini masih semi komputerisasi. Komputer hanya digunakan untuk input data peserta dan nilai 


\begin{tabular}{|c|c|c|}
\hline No & Jenis Analisis & $\begin{array}{c}\text { Kelemahan Sistem Yang } \\
\text { Berjalan }\end{array}$ \\
\hline 2. & $\begin{array}{l}\text { Information } \\
\text { (informasi) }\end{array}$ & $\begin{array}{l}\text { 1. } \text { Belum bisa } \\
\text { memberikan } \\
\text { informasi mengenai } \\
\text { laporan absensi, dan } \\
\text { nilai secara real time. } \\
\text { 2. Dalam menginput } \\
\text { nilai masih sering } \\
\text { terjadi kesalahan } \\
\text { karena dilakukan } \\
\text { manual. } \\
\text { 3. Proses pendataan } \\
\text { masih menggunakan } \\
\text { Kertas, Microsoft } \\
\text { Excel dan Microsoft } \\
\text { Word sehingga } \\
\text { mengalami kesulitan } \\
\text { apabila mencari data } \\
\text { yang dibutuhkan. }\end{array}$ \\
\hline
\end{tabular}

3. Economics Sistem yang berjalan saat (ekonomi) ini membutuhkan banyak kertas, alat tulis, dan tinta printer yang akan membutuhkan biaya cukup besar jika terus diterapkan.

4. Control Tidak adanya keamanan (keamanan) dalam penyimpanan data sehingga siapa saja dapat membuka dokumen dan memanipulasinya.

5. Efficiency (efisiensi)
1. Masih membutuhkan waktu lama untuk pengecekan test peserta diklat. dan nilai yang dikeluarkan panitia masih manual sehingga kurang efisien.

2. Pencarian berkas yang sering kali terselip dan menyulitkan panitia

\begin{tabular}{cclr}
\hline No & Jenis Analisis & \multicolumn{3}{c}{$\begin{array}{c}\text { Kelemahan Sistem Yang } \\
\text { Berjalan }\end{array}$} \\
\hline 6. & $\begin{array}{c}\text { Service } \\
\text { (pelayanan) }\end{array}$ & $\begin{array}{l}\text { Hasil laporan } \\
\text { terlambat karena }\end{array}$ & $\begin{array}{r}\text { yang } \\
\text { proses } \\
\text { akan } \\
\text { yang panjang } \\
\end{array}$ \\
& & $\begin{array}{l}\text { menghambat } \\
\text { keluarnya sertifikat. }\end{array}$
\end{tabular}

\section{Perancangan Sistem}

Tahap selanjutnya dalam penelitian ini adalah perancangan sistem. Perancangan sistem dapat didefinisikan sebagai penggambaran, perencanaan, dan pembuatan sketsa atau pengaturan dari beberapa elemen terpisah ke dalam satu kesatuan yang utuh dan berfungsi [9]. Perancangan sistem diperlukan untuk memberikan gambaran tentang sistem yang akan dibuat, sebelum dibangun sistem yang sesungguhnya, hal tersebut dapat mengurangi kesalahan dalam pembangunan sistem.

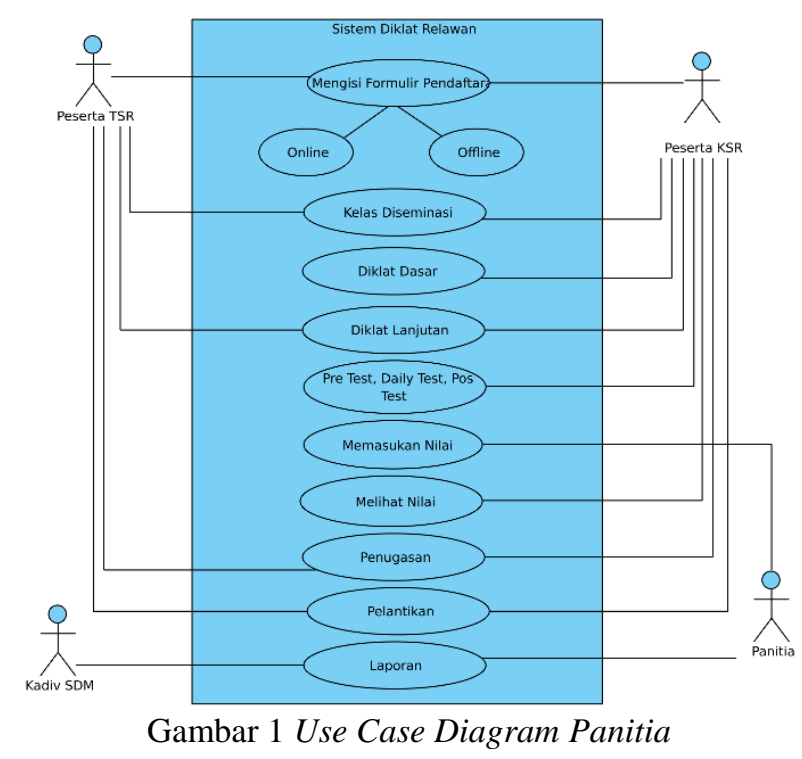

Gambar 1 menunjukan use case diagram pada pembangunan sistem yang dijalankan.

\section{Perancangan Basis Data}

Basis data atau database adalah kegiatan sistem program komputer untuk berbagai aplikasi komputer. Dalam basis data dibutuhkan suatu media simpan komputer yang terorganisir sedemikian rupa dan juga pemeliharaan data baik dalam fungsi manajemen sistem [10]. Rancangan basis data digunakan untuk mempermudah dalam menggambarkan tabel-tabel pada database, serta dapat membantu pemrograman dalam mengambil atau menampilkan data. 


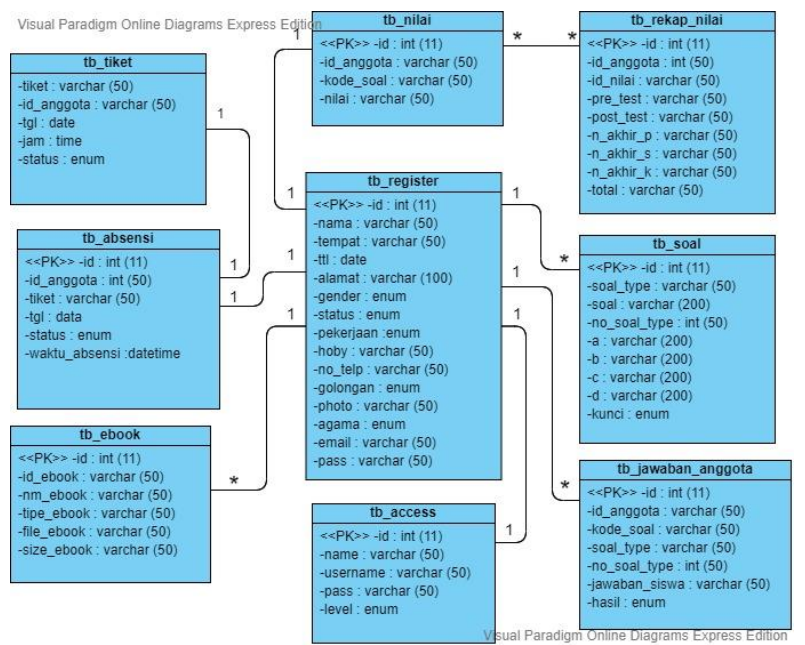

Gambar 2. Class Diagram

Dalam rancangan basis data terdapat 9 tabel yang di gunakan, yaitu tb_registrasi, tb_access, tb_tiket, tb_absensi, tb_ebook, tb_soal, tb_jawaban_anggota, tb_nilai, tb_rekap_nilai.

\section{Implementasi}

Sistem dibangun dengan bahasa pemprograman PHP. Adapun halaman implementasi yang dibuat antara lain:

\section{Halaman Login}

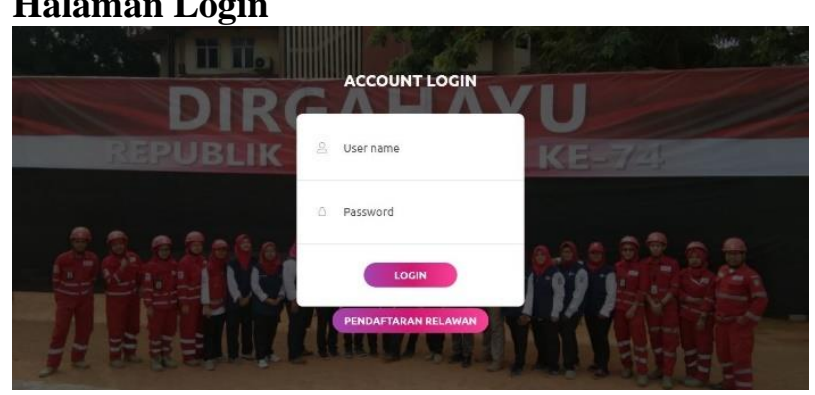

Gambar 3. Tampilan Halaman Login

Panitia dan peserta mengisi username dan password terlebih dahulu untuk masuk kedalam web.

\section{Halaman Home}

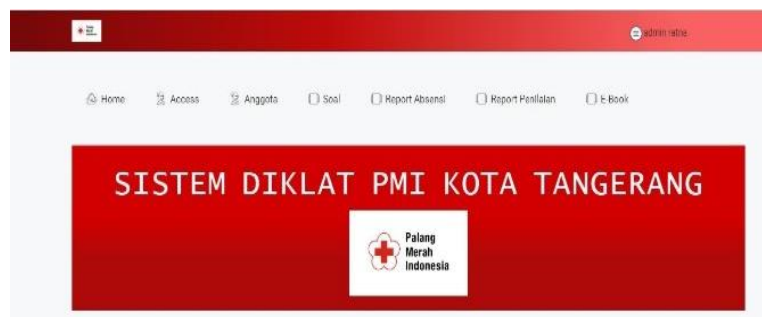

Gambar 4 Tampilan Halaman Home
Setelah Login, User akan diarahkan pada halaman Home.

\section{Profile Peserta}



Tampilan profile peserta menunjukan foto dan data diri peserta. Peserta dapat mengedit profile tersebut.

\section{Halaman Absensi}

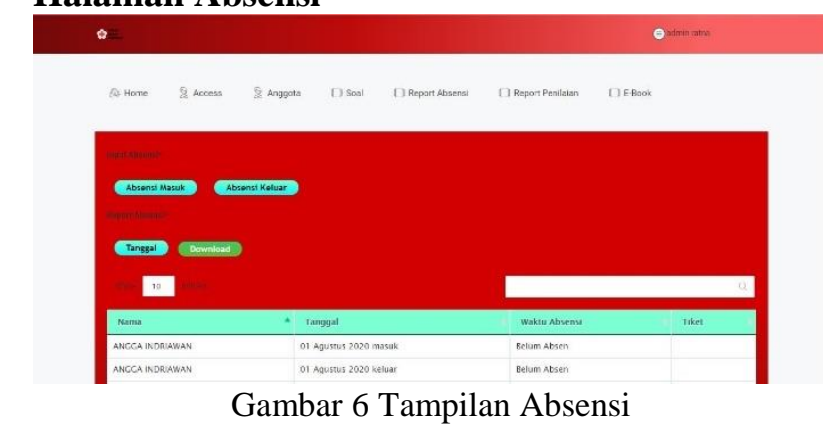

Panitia dapat menginput kode tiket yang diberikan oleh peserta. Peserta mendapatkan tiket dari halaman user masing-masing.

\section{Halaman Soal}

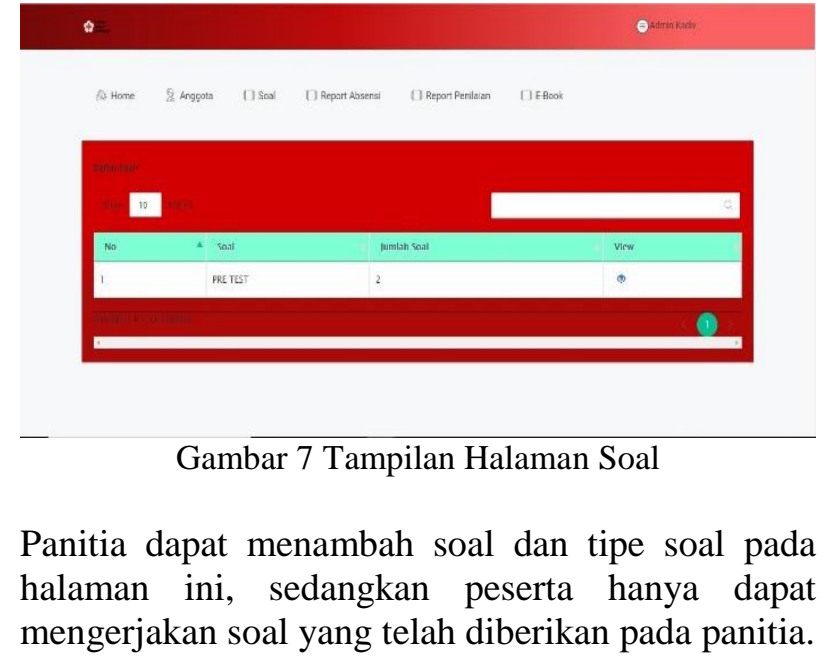




\section{Halaman E-Book}

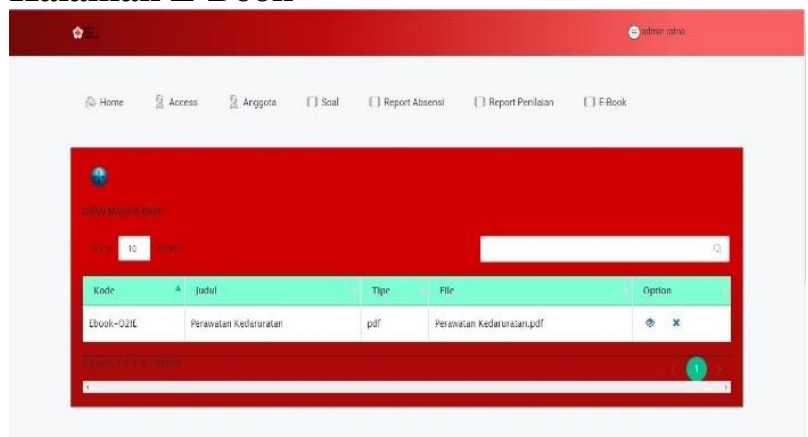

Gambar 8 Tampilan Halaman E-Book

Panitia dapat upload E-Book, sedangkan peserta hanya dapat download E-book.

\section{Halaman Nilai}

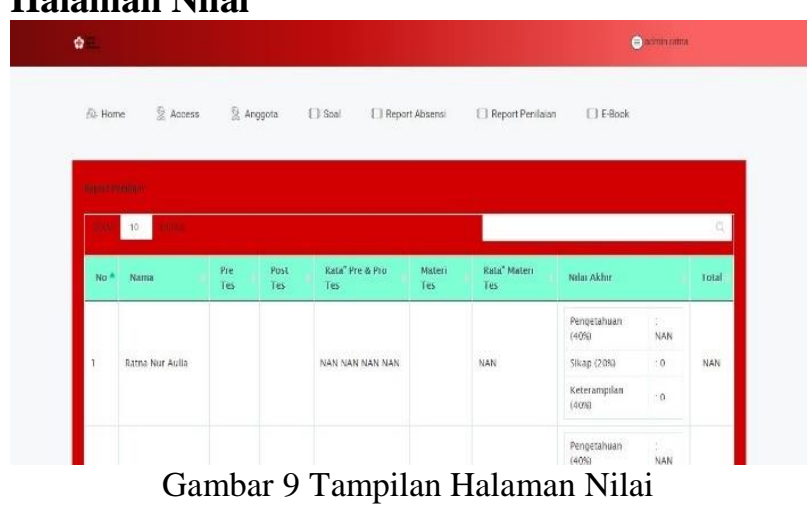

Peserta dapat melihat hasil atau nilai yang didapat seelah mengerjakan soal yang diberikan.

\section{KESIMPULAN}

Sistem yang saat ini digunakan seringkali menghambat waktu untuk pencarian data karena data yang tersebar tidak pada satu sistem. Proses proses dalam pelaksanaan diklat saat ini masih membutuhkan waktu yang lama terutama dalam proses input data peserta. Sistem saat ini masih semi komputerisasi. Komputer hanya digunakan untuk input data peserta dan nilai. Belum bisa memberikan informasi mengenai laporan absensi, dan nilai secara real time.

Dalam menginput nilai masih sering terjadi kesalahan karena dilakukan manual. Proses pendataan masih menggunakan Kertas, Microsoft Excel dan Microsoft Word sehingga mengalami kesulitan apabila mencari data yang dibutuhkan. Sistem yang berjalan saat ini membutuhkan banyak kertas, alat tulis, dan tinta printer yang akan membutuhkan biaya cukup besar jika terus diterapkan. Masih membutuhkan waktu lama untuk pengecekan test peserta diklat. dan nilai yang dikeluarkan panitia masih manual sehingga kurang efisien. Pencarian berkas yang sering kali terselip dan menyulitkan panitia. Sehingga hasil laporan berupa sertifikat menjadi terhambat.

Perancangan Sistem yang dibuat menggunakan sistem analisis permodelan UML (Unified Modeling Language) dengan tujuan untuk memenuhi kebutuhan user dengan alat bantu Sebuah proses desain yang akan menerjemahkan syarat kebutuhan ke sebuah perancangan perangkat lunak yang dapat diperkirakan sebelum dibuat coding. Menggunakan text editor Sublime Text 3 untuk coding program dan XAMPP untuk web server.

\section{UCAPAN TERIMA KASIH}

Terima Kasih kepada pengurus PMI (Palang Merah Indonesia) Kota Tangerang yang telah memberikan izin untuk melakukan penelitian dan menggunakan data-data pendidikan dan pelatihan yang berguna dalam penelitian ini.

\section{REFERENSI}

[1] Suwanto and Priansa, Dasar - dasar Manajemen dalam Organisasi Publik dan Bisnis, Bandung: UPI Press, 2012.

[2] F. Xeviria, A. Djumlani and B. Irawan, "Pelaksanaan Pendidikan dan Pelatihan Aparatur dalam Meningkatkan Kinerja Pegawai di Kantor Dinas Pertambangan dan Energi Kabupaten Kutai Barat Tahun 2015," Jurnal Administrative Reform, vol. 4, no. 3, 2016.

[3] R. Ilyas and Y. Chisnanto, "Pengembangan Sistem Informasi Penelitian LPPM Universitas Jenderal Achmad Yani Dengan Agile SDLC," in Konferensi Nasional Sistem Informasi (KNSI) 2018, 2018.

[4] A. Priyanto and F. Ulinnuha, "Perancangan Aplikasi Penerjemah Bahasa Indonesia Ke Bahasa Jawa untuk Media Bantu Belajar Siste SMK Salafiyah Berbasis Android," Indonesian Journal Networking and Security, vol. 6, 2017.

[5] A. Wahyuni and M. Kom, "Sistem Pendukung Keputusan Pemilihan Jurusan Di Sekolah Menengah Kejuruan 1 Cengkareng Jakarta," Jurnal Interkom, vol. 12, no. 3, 2017. 
[6] M. Suhartanto, "Pembuatan Website Sekolah Menengah Pertama Negeri 3 Delanggu dengan Menggunakan PHP dan MYSQL," Journal Speed, vol. 4, no. 1, 2012.

[7] R. M. N. Halim, "Rancang Bangun Sistem Pengolahan Data Peserta Diklat di LP3SDM Azra Palembang," Jurnal Ilmiah Matrik, vol. 18, no. 3, 2016.

[8] M. R. Ridha, Usman and D. Y. Prasetyo, "Desain Dan Implementasi Sistem Informasi Akademik (Studi Kasus Fakultas Ilmu Agama
Islam Universitas Islam Indragiri)," Jurnal Buana Informatika, vol. 6, no. 2, 2015.

[9] P. D. Astuti, "Sistem Informasi Penjualan Obat Pada Apotek Jati Farma Arjosari," Jurnal Speed, vol. 3, no. 4, 2011.

[10] K. Yuliana, Saryani and N. Azizah, "Perancangan Rekapitulasi Pengiriman Barang Berbasis WEB," Jural SISFOTEK, vol. 9, no. 1, 2019. 